\title{
Determination of Physical and Mechanical Properties of Pomegranate (Var. bhagwa) Fruit and Aril
}

\author{
B. Jithender ${ }^{1^{*}}$, D.M. Vyas ${ }^{2}$, S. Abhisha ${ }^{2}$ and P.J. Rathod ${ }^{3}$ \\ ${ }^{1}$ Department of Agricultural Processing and Structure, CIAE, Bhopal, M.P., India \\ ${ }^{2}$ Department of Processing and Engineering, CAET, JAU, Junagadh, Gujarat, India \\ ${ }^{3}$ College of Agriculture, Department of Biochemistry, JAU, Junagadh, Gujarat, India \\ *Corresponding author
}

\begin{tabular}{|c|c|}
\hline & A B S T R A C T \\
\hline & \multirow{6}{*}{$\begin{array}{l}\text { Freshly harvested and fully matured pomegranate fruits variety (Bhagwa) was procured } \\
\text { from nearby private orchard. The physical and mechanical properties pomegranate fruits } \\
\text { and arils were determined which are required in design of various cleaning, grading, } \\
\text { transporting, juice extractor machines, packaging equipments etc. The physical properties } \\
\text { of pomegranate fruits (var. Bhagwa) and arils were found that the length, thickness, width, } \\
\text { geometric mean diameter, sphericity, aspect ratio and surface area, with their standard } \\
\text { deviation and mean were } 76.56 \pm 3.91 \mathrm{~mm}, 72.61 \pm 2.85 \mathrm{~mm}, 68.81 \pm 3.55 \mathrm{~mm}, 72.39 \pm 2 \mathrm{~mm} \text {, } \\
0.948 \pm 0.049,0.945 \pm 0.067,227.30 \pm 6.29 \mathrm{~mm}^{2} \text { and } 9.91 \pm 1.27 \mathrm{~mm}, 7.81 \pm 0.93 \mathrm{~mm} \text {, } \\
6.149 \pm 0.826 \mathrm{~mm}, 7.80 \pm 0.843 \mathrm{~mm}, 0.791 \pm 0.06,0.80 \pm 0.09,24.50 \pm 2.65 \mathrm{~mm}^{2}, \text { respectively. } \\
\text { The other physical properties such as bulk density, true density, porosity, density ratio } \\
\text { were determined for pomegranate fruits and arils were found as } 651.23 \pm 26.29 \mathrm{~kg} / \mathrm{m}^{3} \text {, } \\
980.11 \pm 26.55 \mathrm{~kg} / \mathrm{m}^{3}, 33.48 \pm 3.84 \%, 0.66 \pm 0.04 \text { and } 584.54 \pm 55.50 \mathrm{~kg} / \mathrm{m}^{3}, 1039.16 \pm 22.47 \\
\mathrm{~kg} / \mathrm{m}^{3}, 43 \pm 5.72 \%, 0.56 \pm 0.06 \text {, respectively. The average coefficient of friction of } \\
\text { pomegranate fruit and arils on glass, galvanized iron and wood were found as } \\
0.437 \pm 0.030,0.794 \pm 0.04 \text { and } 0.857 \pm 0.01 \text { and } 0.354 \pm 0.027 \text {, } 0.523 \pm 0.016 \text {, } 0.574 \pm 0.01 \text {, } \\
\text { respectively. The mechanical properties of pomegranate fruit and arils, such as average } \\
\text { cutting force, hardness and crushing force of pomegranate fruit and crushing force for arils } \\
\text { were found as } 22.28 \pm 1.115,45.59 \pm 0.886,25 \pm 0.823 \text { and } 1.65 \mathrm{kgf} \text {, respectively. }\end{array}$} \\
\hline & \\
\hline $\begin{array}{l}\text { Shpericity, Bulk } \\
\text { density, Coefficient } \\
\text { of friction, Cutting } \\
\text { force, Crushing } \\
\text { force, Hardness. }\end{array}$ & \\
\hline Article Info & \\
\hline $\begin{array}{l}\text { Accepted: } \\
\text { 10 September } 2017 \\
\text { Available Online: } \\
10 \text { October } 2017\end{array}$ & \\
\hline & \\
\hline
\end{tabular}

\section{Introduction}

The name pomegranate is derives from the Latin word pomum meaning apple and granatus meaning seeded (Karkare and Siddique, 2012). The pomegranate has been grown since ancient times for its delicious fruits and as an ornamental garden plant for its red, orange or occasionally, creamy yellow flowers. The pomegranate (Punica granatum L.) belongs to the Punicaceae family. It is also known as the Chinese apple or Apple of Carthage or Apple with many seeds (Schubert et al., 1999). The edible parts of pomegranate fruits are consumed fresh or used for the preparation of fresh juice, canned beverages, wines, jelly, jam, and paste and also for flavoring and coloring beverage products.

Pomegranate fruit are rich source of proteins, vitamins, minerals and having wider application in medicine both in Ayurvedic and Unani system (Fadavi et al., 2006 and Mousavinejad et al., 2009). 
Physical properties of pomegranate fruit was determined by its weight ranged from 103.38 to $505.00 \mathrm{~g}$ and fruit volume from 99.41 to $547.88 \mathrm{~cm}^{3}$. Similarly, average three fruits' density ranged from 0.91 g.cm ${ }^{-3}$ to $1.04 \mathrm{~g} . \mathrm{cm}^{-3}$ and peel thickness of the fruit was recorded from 1.60 to $6.01 \mathrm{~mm}$ (Vahid et al., 2009).

Investigated some physical characteristics of pomegranate, its seeds and arils. Physical properties of fruit were determined and average value of length, width, thickness, geometric mean diameter, sphericity, surface area, criteria project area and porosity were found as $88.12 \mathrm{~mm}, 82.61 \mathrm{~mm}, 79.65 \mathrm{~mm}$, $83.33 \mathrm{~mm}, 0.95$ percent, $219.91 \mathrm{~cm}^{2}, 57.90$ $\mathrm{cm}^{2}, 29.402 \mathrm{~cm}^{2}$ respectively. Coefficient of friction of fruit on wood, glass and galvanized Iron surface were $0.45,0.72$ and 0.84 , respectively. Mean values of coefficient of friction on these surfaces were $0.53,0.31$, 0.50 and $0.58,0.30$ and 0.49 for arils and seeds, respectively. Weight ratio different parts of samples were determined and average value were 0.73 for arils respect to fruit and 0.25 for peels respect to fruit (Riyahi et al., 2011).

\section{Materials and Methods}

Freshly harvested and fully matured pomegranate fruits (Var. Bhagwa) was procured from nearby private orchards for determine the some of the physical and mechanical properties such as size, shape, surface area, volume, bulk density, porosity, true porosity, coefficient of friction, cutting force, crushing force and hardness were determined using standard procedures/instruments as shown below.

\section{Measurement of fruit and arils size}

The linear dimensions of the pomegranate fruits and arils were determined by using a digital vernier calliper in terms of length, thickness and width of the fruit denoted as a, b and c respectively. 20 samples were selected at random and measured when the fruit is at a state of rest and were gently raised up to measure its thickness. This was determined at a single moisture level having ascertained that increasing the moisture content of the fruit does not have any significant effect on its linear dimensions. The size was also expressed in terms of geometric mean diameter and equivalent surface area. These were determined from the values obtained from linear dimensions as reported by Balasubramanian (2001) and Barych (2000).

The geometric mean diameter was calculated as:

$\mathrm{D}_{\mathrm{e}}=(\mathrm{abc})^{1 / 3}(1)$

The equivalent surface area of the fruit was evaluated using equation as reported by Barych (2000):

$\mathrm{S}=\pi\left(\mathrm{D}_{\mathrm{e}}\right)^{2}(2)$

The shape of the pomegranate fruits would be determined from the values obtained for length, width and thickness. The shape of the fruits described and evaluated in terms of its sphericity ratio index and aspect ratio as:

$\mathrm{S}_{\mathrm{p}}=\frac{\mathrm{abc} \mathrm{c}^{1 / 3}}{\mathrm{a}}(3)$

The aspect ratio $\left(\mathrm{R}_{\mathrm{a}}\right)$ was calculated as recommended by Maduako and Faborode (1990) as:

$\mathrm{R}_{\mathrm{a}}=\frac{\mathrm{b}}{\mathrm{a}} \times 100 \%$

\section{Bulk density}

Bulk density which is defined as the ratio of the mass of the sample to its container volume was calculated as per the procedure suggested 
by Barych (2000).

$\rho_{b}=\frac{\text { mass }}{\text { volume }}=\frac{\mathrm{m}}{\mathrm{v}}(5)$

\section{True density}

The volume and true density of fresh pomegranate fruits was determined by toluene displacement method. Toluene was used because it is absorbed by sample to a lesser extent the true density was calculated from the volume of toluene displaced and the mass of sample and calculated as reported by (Sacilik et al., 2003).

$\rho_{t}=\frac{W}{V}(6)$

Where,

$\rho_{\mathrm{t}}=$ True density, $\mathrm{kg} \cdot \mathrm{m}^{-3}$

$\mathrm{W}=$ Mass of pomegranate fruit in $\mathrm{kg}$.

$\mathrm{V}=$ Volume of toluene displaced by the sample, $\mathrm{m}^{3}$.

\section{Porosity}

From the value of bulk density and true density, using the following expression as described by Mohsenin (1986) the porosity was calculated.

$\varepsilon=\left[1-\left(\rho_{\mathrm{b}} / \rho_{\mathrm{t}}\right) \times 100\right](7)$

\section{Density ratio}

The density ratio (Dt) is expressed as a percentage was calculated as per the methodology given by (Owolarafe et al., 2006) and using the relationship.

$D_{t}=\frac{P_{b}}{P_{t}}(8)$

\section{Coefficient of friction}

The coefficient of friction on three surfaces namely glass, wood and G.I was determined using an angularly adjustable base with a graduated scale in degree (Datta et al., 1988).

$\mu=\tan \theta(9)$

Where,

$\mu=$ Coefficient of friction.

$\theta=$ Angle of static friction, degree.

\section{Cutting force}

Texture profile analyzer XT Plus (Stable Micro System Ltd.) was used with a blade set knife. For each test, a single pomegranate fruit was positioned with its stem/calyx axis parallel to the platform. The texture profile analyzer was calibrated with a $50 \mathrm{~kg}$ load cell.The operating conditions for the profile analyzer was followed as pre-test speed 1 $\mathrm{mm} / \mathrm{s}$, probe test speed $1 \mathrm{~mm} / \mathrm{s}$, posttest speed $10 \mathrm{~mm} / \mathrm{s}$, cutting force $1000 \mathrm{~N}$ and cutting distance $60 \mathrm{~mm}$. The data obtained from the textural profile analyzer were interpreted using software Exponent v.4. The software was used to run macro, which was used to evaluate the cutting force and energy. Fruit cutting test was carried out on opposite side of 6 randomly selected fruits, similar in size and a value for 6 determinations was expressed as mean $\pm \mathrm{SE}$.

\section{Hardness}

Fruit hardness was measured using a texture profile analyzer XT Plus (Stable Micro System Ltd., Godalming, UK) with a $60 \mathrm{x}$ $60 \mathrm{~mm}$, P70 crushing platen probe. The texture profile analyzer was calibrated with a $50 \mathrm{~kg}$ load cell. The operating conditions for the profile analyzer were as follows: pre-test speed $1.5 \mathrm{~mm} / \mathrm{s}$, probe test speed $1 \mathrm{~mm} / \mathrm{s}$, 
post-test speed $10.0 \mathrm{~mm} / \mathrm{s}$, crushing force $1000 \mathrm{~N}$, and deformation distance $30 \mathrm{~mm}$. A single fruit was placed on a steel test platform, with the stem/ calyx axis parallel to the platform, and a force deformation curve was obtained for each test.

\section{Fruit crushing}

Fruit crushing was studied using a texture profile analyzer XT Plus (Stable Micro System Ltd., Godalming, UK) with a 60 x 60 $\mathrm{mm}, \mathrm{P} 70$ crushing platen probe. The texture profile analyzer was calibrated with a $50 \mathrm{~kg}$ load cell. The operating conditions for the profile analyzer were kept as pre-test speed $1.5 \mathrm{~mm} / \mathrm{s}$, probe test speed $1 \mathrm{~mm} / \mathrm{s}$, post-test speed $10.0 \mathrm{~mm} / \mathrm{s}$, crushing force $1000 \mathrm{~N}$, and deformation distance $30 \mathrm{~mm}$. A whole fruit cut into half after that half of the cut fruit was placed on a steel test platform and a force deformation curve was obtained for each test.

\section{Aril crushing test}

Aril crushing test was performed using a texture profile analyzer XT Plus (Stable Micro System Ltd.), with a $35 \mathrm{~mm}$ diameter cylindrical crushing probe. Crushing test was performed on individual arils with the following operating conditions: pre-test speed $1.5 \mathrm{~mm} / \mathrm{s}$, probe test speed $1 \mathrm{~mm} / \mathrm{s}$, posttest speed $10.0 \mathrm{~mm} / \mathrm{s}$, compression force $10 \mathrm{~N}$, and compression distance $10 \mathrm{~mm}$. The data obtained from the textural analyzer were interpreted using software Exponent v.4 (Stable Micro System Ltd.). Aril crushing test was done on 6 randomly selected fruits and the results presented as mean $\pm \mathrm{SE}$ of 6 determinations are reported.

\section{Results and Discussion}

\section{Physical and mechanical properties of fruits and arils}

The length, thickness, width, geometric mean diameter, sphericity, aspect ratio and surface area of pomegranate fruits and arils were found to be $76.56 \pm 3.91 \mathrm{~mm}, 72.61 \pm 2.85$ $\mathrm{mm}, \quad 68.81 \pm 3.55 \mathrm{~mm}, \quad 72.39 \pm 2 \mathrm{~mm}$, $0.948 \pm 0.049, \quad 0.945 \pm 0.067, \quad 227.30 \pm 6.29$ $\mathrm{mm}^{2}$ and $9.91 \pm 1.27 \mathrm{~mm}, 7.81 \pm 0.93 \mathrm{~mm}$, $6.149 \pm 0.826 \mathrm{~mm}, \quad 7.80 \pm 0.843 \mathrm{~mm}$, $0.791 \pm 0.06, \quad 0.80 \pm 0.09,24.50 \pm 2.65 \mathrm{~mm}^{2}$, respectively.

The average value of bulk density of pomegranate fruits and arils were found to be $651.23 \pm 26.29$ and $584.54 \pm 55.50 \mathrm{~kg} / \mathrm{m}^{3}$, respectively.

The average true density of pomegranate fruits and arils were found to be $980.11 \pm 26.55$ and $1039.16 \pm 22.47 \mathrm{~kg} / \mathrm{m}^{3}$, respectively.

The average porosity and density ratio of pomegranate fruits and arils were found to be $33.48 \pm 3.84, \quad 43 \pm 5.72 \%$ and $0.66 \pm 0.04$, $0.56 \pm 0.06$, respectively.

Table.1 Bulk density of pomegranate fruits and arils

\begin{tabular}{|c|c|c|c|c|c|c|}
\hline \multicolumn{4}{|c|}{ Pomegranate fruits } & \multicolumn{3}{|c|}{ Arils } \\
\hline Sr.No & $\begin{array}{l}\text { Weight of } \\
\text { fruits (kg) }\end{array}$ & $\begin{array}{l}\text { volume of container } \\
\left(\mathbf{m}^{\mathbf{3}}\right)\end{array}$ & $\begin{array}{l}\text { Bulk density } \\
\left(\mathrm{kg} / \mathrm{m}^{3}\right)\end{array}$ & $\begin{array}{l}\text { Weight of } \\
\text { arils (kg) }\end{array}$ & $\begin{array}{c}\text { Cylinder } \\
\text { volume }\left(\mathbf{m}^{3}\right)\end{array}$ & $\begin{array}{c}\text { Bulk density } \\
\left(\mathrm{kg} / \mathrm{m}^{3}\right)\end{array}$ \\
\hline 1 & 2.99 & 0.00432 & 692.12 & 0.043 & 0.000069 & 623.18 \\
\hline 2 & 2.68 & 0.00432 & 620.37 & 0.046 & 0.000069 & 666.66 \\
\hline 3 & 2.85 & 0.00432 & 659.72 & 0.04 & 0.000069 & 579.71 \\
\hline 4 & 2.81 & 0.00432 & 650.46 & 0.038 & 0.000069 & 550.72 \\
\hline 5 & 2.7 & 0.00432 & 625 & 0.035 & 0.000069 & 507.24 \\
\hline 6 & 2.85 & 0.00432 & 659.72 & 0.04 & 0.000069 & 579.71 \\
\hline Mean & & & 651.23 & & & 584.54 \\
\hline Std. dev. & & & 26.29 & & & 55.50 \\
\hline
\end{tabular}


Table.2 True density of pomegranate fruits and arils

\begin{tabular}{|c|c|c|c|c|c|c|}
\hline \multicolumn{3}{|c|}{ Pomegranate fruits } & \multicolumn{3}{c|}{ Arils } \\
\hline Sr.No & $\begin{array}{c}\text { Weight } \\
\text { of fruits } \\
(\mathbf{k g})\end{array}$ & $\begin{array}{c}\text { Displaced } \\
\text { volume (m) })\end{array}$ & $\begin{array}{c}\text { True density } \\
\left(\mathbf{k g} / \mathbf{m}^{\mathbf{3}}\right)\end{array}$ & $\begin{array}{c}\text { Weight } \\
\text { of arils } \\
(\mathbf{k g})\end{array}$ & $\begin{array}{c}\text { Displaced } \\
\text { volume } \\
(\mathbf{m l})\end{array}$ & $\begin{array}{c}\text { True } \\
\mathbf{d e n s i t y} \\
\left(\mathbf{k g} / \mathbf{m}^{\mathbf{3}}\right)\end{array}$ \\
\hline 1 & 0.195 & 205 & 951.22 & 68 & 65 & 1046 \\
\hline 2 & 0.205 & 207 & 990.34 & 62 & 59 & 1050 \\
\hline 3 & 0.168 & 170 & 988.24 & 60 & 58 & 1034 \\
\hline 4 & 0.198 & 210 & 942.86 & 61 & 60 & 1016 \\
\hline 5 & 0.3 & 305 & 983.61 & 58 & 54 & 1074 \\
\hline 6 & 0.21 & 215 & 1024.39 & 66 & 65 & 1015 \\
\hline Mean & & & 980.11 & & & 1039.16 \\
\hline Std. dev. & & & 29.55 & & & 22.471 \\
\hline
\end{tabular}

Table.3 Porosity and density ratio of pomegranate fruits and arils

\begin{tabular}{|c|c|c|c|c|}
\hline \multicolumn{3}{|c|}{ Pomegranate fruits } & \multicolumn{2}{c|}{ Arils } \\
\hline Sr. No. & Porosity (\%) & Density ratio & Porosity (\%) & Density ratio \\
\hline 1 & 27.24 & 0.73 & 40.42 & 0.60 \\
\hline 2 & 37.36 & 0.63 & 36.51 & 0.63 \\
\hline 3 & 33.24 & 0.67 & 43.94 & 0.56 \\
\hline 4 & 31.01 & 0.69 & 45.79 & 0.54 \\
\hline 5 & 36.46 & 0.64 & 52.77 & 0.47 \\
\hline 6 & 35.60 & 0.64 & 42.89 & 0.57 \\
\hline Mean & 33.48 & 0.66 & 43.72 & 0.56 \\
\hline Std. dev. & 3.83 & 0.04 & 5.47 & 0.06 \\
\hline
\end{tabular}

Table.4 Mechanical properties

\begin{tabular}{|c|c|c|c|c|}
\hline \multicolumn{4}{|c|}{ Pomegranate fruits } & \multirow{2}{*}{$\begin{array}{c}\text { Arils } \\
\text { Crushing } \\
\text { force (kgf) }\end{array}$} \\
\hline Sr. No & $\begin{array}{l}\text { Cutting force } \\
\text { fruit (kgf) }\end{array}$ & $\begin{array}{l}\text { Hardness } \\
\text { (kgf) }\end{array}$ & $\begin{array}{l}\text { Crushing } \\
\text { force (kgf) }\end{array}$ & \\
\hline 1 & 22.66 & 46 & 26 & 1.825 \\
\hline 2 & 21.42 & 45.42 & 27.12 & 1.675 \\
\hline 3 & 23.27 & 44.15 & 25.86 & 1.586 \\
\hline 4 & 23.86 & 45.75 & 26.47 & 1.728 \\
\hline 5 & 20.94 & 46.85 & 24.98 & 1.563 \\
\hline 6 & 21.56 & 45.38 & 25.1 & 1.523 \\
\hline Mean & 22.285 & 45.591 & 25.921 & 1.65 \\
\hline Std. dev. & 1.155 & 0.886 & 0.813 & 0.114 \\
\hline
\end{tabular}


The average coefficient of friction of pomegranate fruit and arils on glass, galvanized iron and wood was of the order of $0.437 \pm 0.030,0.794 \pm 0.04$ and $0.857 \pm 0.01$ and $0.354 \pm 0.027, \quad 0.523 \pm 0.016 \quad \& 0.574 \pm 0.01$, respectively.

From the results in regards of physical properties of pomegranate fruits (var. Bhagwa), it was found that the length, thickness, width, geometric mean diameter, sphericity, aspect ratio and surface area, with their standard deviation and mean was $76.56 \pm 3.91 \mathrm{~mm}, 72.61 \pm 2.85 \mathrm{~mm}, 68.81 \pm 3.55$ $\mathrm{mm}, 72.39 \pm 2 \mathrm{~mm}, 0.948 \pm 0.049,0.949 \pm 0.067$, $227.30 \pm 6.29 \mathrm{~mm}^{2}$ and $9.91 \pm 1.27 \mathrm{~mm}$, $7.81 \pm 0.93 \mathrm{~mm}, \quad 6.149 \pm 0.826 \mathrm{~mm}$, $7.80 \pm 0.843 \mathrm{~mm}, 0.174 \pm 0.066,0.80 \pm 0.09$, $24.50 \pm 2.65 \mathrm{~mm}^{2}$, respectively.

The other physical properties such as bulk density, true density, porosity, density ratio were determined for pomegranate fruits and arils were found as $651.23 \pm 26.29 \mathrm{~kg} / \mathrm{m}^{3}$, $980.11 \pm 26.55 \mathrm{~kg} / \mathrm{m}^{3}, \quad 33.48 \pm 3.84 \%$, $0.66 \pm 0.04$ and $584.54 \pm 55.50 \mathrm{~kg} / \mathrm{m}^{3}$, $1039.16 \pm 22.47 \mathrm{~kg} / \mathrm{m}^{3}, 43 \pm 5.72 \%$, $0.56 \pm 0.06$, respectively (Tables $1-4$ ).

The average coefficient of friction of pomegranate fruits and arils on glass, galvanized iron and wood were found to be $0.437 \pm 0.030,0.794 \pm 0.04$ and $0.857 \pm 0.01$ and $0.354 \pm 0.027, \quad 0.523 \pm 0.016, \quad 0.574 \pm 0.01$, respectively.

The results on physical properties was in line with the results obtained by Vahid et al., (2009), Riyahi et al., (2011), Hazbavi (2013) and Kumar et al., (2015).

The physical and mechanical properties of pomegranate fruit and arils to be used for design of various cleaning, grading, transporting, juice extractor machines, packaging equipments etc.

\section{References}

Balasubramanian, D., 2001. Physical properties of raw cashew nut. J. Agric. Eng. Res. 78(3): 291-297.

Barych, E. A., 2000. Physical properties of bambara groundnuts. Journal of Food Engineering. 47: 321-326.

Datta, S. K.; Nema, V. K. and Bhardwaj, R. K. 1988. Physical properties of gram. $J$. Agric. Engng. Res. 3(9): 259-268.

Fadavi, A.; Barzegar, M. and Azizi, H.M. 2006. Determination of fatty acids and total lipid content in oilseed of 25 pomegranates varieties grown in Iran. $J$ Food Comp Anal. 19: 676-680.

Hazbavi, 2013. Determination of engineering properties of pomegranate fruit to calculation the height of box for handling. IJSIT. 2(6): 492-501.

Karkare, S., and Siddique, F. K. 2012. Role of pomegranate in preventive dentistry. IJRAP. 3(5): 648-649.

Maduako, J. N., and Faborode, M. O. 1990. Some physical properties of cocoa pods in relation to primary processing. Ife Journal of Technology. 2: 1-7.

Moshsenin, N.N., 1986. Physical properties of animal and plant material. Gordon and Breach Science Publishers, U.S.A.

Owolarafe, O. K.; Adeboye, O. C. and Adegbenjo, O. A. 2006. Physical properties and food value of Spondias mombin L. an under exploited fruit of Nigeria. Journal food Science and Technology. 43(6): 626 - 629 .

Riyahi, R.; Rafiee, S.; Dalvand, M. J. and Keyhani, A. 2011. Some physical characteristics of pomegranate, seeds and arils. Journal of Agricultural Technology. 7(6): 1523-1537.

Sacilik, K. R.; Ozturk, R and Keskin, R. 2003. Some physical properties of hemp seed. Bio Systems Engineering. 86(2): 191198.

Schubert, S. Y.; Lansky, E. P. and Neeman, I. 
1999. Antioxidant and eicosanoid enzyme inhibition properties of pomegranate seed oil and fermented juice flavonoids. Journal of Ethno Pharmacology. 6(6): 11-17.
Vahid, A.; Khodayar, H. and Mehdi, S. 2009. Physical and chemical properties of pomegranate (Punica granatum L.) fruit in maturation stage. American-Eurasian J. Agric. Environ. Sci. 6(4): 411-416.

\section{How to cite this article:}

Jithender, B., D.M. Vyas, S. Abhisha and Rathod, P.J. 2017. Determination of Physical and Mechanical Properties of Pomegranate (Var. bhagwa) Fruit and Aril. Int.J.Curr.Microbiol.App.Sci. 6(10): 879-885. doi: https://doi.org/10.20546/ijcmas.2017.610.105 